\title{
Izraelskie narracje o Zagładzie
}

I niech wzgórze pamięci pamięta zamiast mnie

יהודה עמיחי, בתוך “שירי ארץ ציון ירושלים":

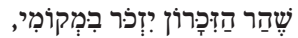

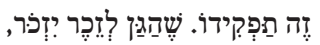

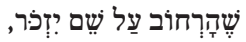

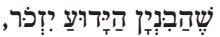

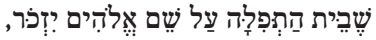

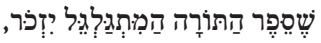

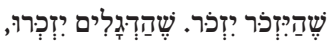

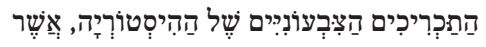

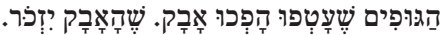

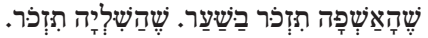

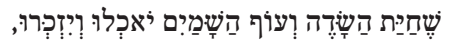

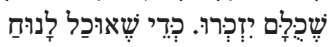

to jego zadanie. I niech ogród pamięci pamięta

i niech ulica imienia pamięta

niech pamięta słynna budowla

niech pamięta dom modlitwy imienia Pana Boga

I niech Jizkor pamięta/i flagi, niech pamiętają

i barwne całuny historii kryjące

ciała, co obróciły się w proch. Niech proch pamięta.

[...] niech wszyscy pamiętają, a mnie dadzą odpocząć.

J. Amichaj: Meachorej kol...1

Wiersz Niech wzgórze pamięci pamięta zamiast mnie, napisany przez Jehudę Amichaja w latach 80. XX wieku, doskonale oddaje (nad)obecność Zagłady

${ }^{1}$ J. Aмichaj: Meachorej kol ze mistater oszer gadol. Jeruszalajim we-Tel-Awiw 1985, s. 26; tłum. fragm. - J. Budzik. 
w Państwie Izrael, na poszczególnych etapach jego rozwoju i wśród rozmaitych grup składających się na izraelskie społeczeństwo. Szoa angażuje wszystkie obszary życia publicznego - porządek świecki i religijny, narodową mitologię żydowsko-syjonistyczną tkwiącą w samych fundamentach państwa i tworzące je instytucje, narrację historyczną oraz literacką. Istotnie, wszystkie te obszary nieustannie uczestniczą w konstruowaniu izraelskiej, zbiorowej pamięci o Zagładzie. Wyłaniające się z ostatniego wersu wiersza Amichaja świadectwo przesilenia, wyczerpania wszechobecnością pamięci zwraca też uwagę na szeroką skalę przyjmowanych wobec zagładowego dyskursu postaw: od przekonania o niepodważalności opowiadanej instytucjonalnie wersji historii, przez jej akceptację i uznanie konieczności, aż po krytykę (bywa, że bardzo radykalną) niektórych jej użyć.

Niebywałą złożoność izraelskich narracji widać na wielu poziomach, począwszy od zupełnie podstawowego - języka. W przeciwieństwie do europejskich pamięci narodowych pamięć izraelska nie może zostać określona jako hebrajska, choć z oczywistych względów dzisiejszy język większości izraelskich Żydów pełni funkcję dominującą. Izraelska pamięć Zagłady jest jednak zjawiskiem wielojęzycznym: jidyszowym, polskim, niemieckim, francuskim, węgierskim, czeskim, rumuńskim, a także - last but not least - angielskim. Całościowe uchwycenie zjawiska wielojęzyczności dyskursu o Szoa wydaje się zadaniem niewykonalnym, w niniejszym numerze „Narracji o Zagładzie” zdecydowaliśmy się zatem skupić przede wszystkim na narracjach hebrajskich i polskich, jak również na kwestii hebrajsko-polskiego dwugłosu. W obliczu wciąż niewystarczającej obecności wątków izraelskich w polskim namyśle nad Zagładą i jej następstwami taki rozkład akcentów wydał nam się najlepszym rozwiązaniem, mającym wskazać Czytelnikowi punkt wyjścia do dalszych refleksji i odkrywania kolejnych zjawisk z tego obszaru. Ujmując rzecz nieco inaczej, zależało nam po prostu na popularyzacji tego tematu i ukazaniu związanych z nim komplikacji. Symbolem tak zarysowanej perspektywy uczyniliśmy niepublikowane wcześniej w Polsce opowiadanie Idy Fink Na wczasach. Pisarka do końca życia tworzyła i mówiła w domu po polsku, uważając się jednocześnie za Izraelkę. Paradoks ten, jeden $\mathrm{z}$ wielu, podobnie jak wszechobecność Zagłady, o czym również traktuje utwór Fink, warto mieć stale na uwadze.

Jak wskazuje między innymi izraelska literaturoznawczyni Nurit Gowrin, temat Zagłady jest obecny w izraelskiej - przed 1948 rokiem także w erec izraelskiej - kulturze od samego początku, to znaczy od momentu, gdy na ówczesne tereny Palestyny zaczęły docierać pierwsze wieści o tragicznym losie europejskich Żydów ${ }^{2}$. Jednocześnie miejsce Zagłady w izraelskim dyskursie publicznym i w narracjach kulturowych ulegało przez lata licznym fluktuacjom. Ele-

2 Zob. N. Gowrin: במעגליה עברית ספרות הדורות קריאת [„Czytając Pokolenia. Studia kontekstowe z literatury hebrajskiej"]. Tel Awiw 2015, s. 241. 
mentami silnie różnicującymi poszczególne etapy wielogłosowego opowiadania Zagłady przez kulturę współczesnego Izraela są więc w oczywisty sposób czas i przemiany społeczno-polityczne, kształtujące rzeczywistość nowo powstałego państwa. Zarówno rozmowy z naszymi gośćmi - Piotrem Pazińskim i Shoshaną Ronen - jak i niektóre zawarte w tym numerze artykuły skupiają się zatem na immanentnej dynamice izraelskiego, zagładowego dyskursu i zależnościach między nim a wydarzeniami z krótkiej - choć burzliwej - historii Państwa Izrael. Poszczególne opowieści nadbudowane zostały przecież na tekstach powstających od chwili pierwszych doniesień o Szoa, docierających do Erec Israel w grudniu 1942 roku. (Od)tworzone przez indywidualną pamięć ocalałych podlegały z kolei modyfikacjom, którym ulegał zbiorowy dyskurs na skutek kluczowych, odbywających się w 1961 i 1988 roku procesów nazistowskich zbrodniarzy: Adolfa Eichmanna i Iwana Demianiuka. Przemiany zagładowego decorum mają też coraz częściej charakter ponadlokalny. Najnowsze - opisane bodaj najpełniej przez Natana Sznaidera i Daniela Levy'ego ${ }^{3}$ - zjawisko globalizacji pamięci o Szoa przejawia się w intensywnym przyroście zagładowych klisz, które z kolei stanowią popularny język wykorzystywany do opisu innych ludobójstw, na co zwracał uwagę choćby Michael Rothberg w Pamięci wielokierunkowej... ${ }^{4}$ W tej perspektywie narracje o Szoa powstające w Izraelu w ostatnich latach (zob. szkic Jagody Budzik) być może najsilniej łączą spojrzenie lokalne z szerszymi procesami, w mniejszym stopniu warunkowanymi geograficznie i narodowo.

O przeobrażeniach kulturowych wpływających na kształt izraelskiej pamięci o Zagładzie napisano wiele. Po polsku ukazały się między innymi publikacje badaczy z pokolenia tzw. izraelskich nowych historyków - Siódmy milion... Toma Segeva ${ }^{5}$ oraz Naród i śmierć... Idith Zertal ${ }^{6}$. Wciąż niewiele jest jednak polskojęzycznych prac skupiających się na samych opowieściach. Odwołujących się do ogromnego korpusu izraelskich, literackich tekstów dotyczących Zagłady, a także niezliczonych reprezentacji z zakresu kina i sztuk wizualnych oraz kultury popularnej. Kolejną cechą wskazującą na złożoność zjawiska jest bowiem jego intermedialność. W trakcie przygotowywania tego numeru dość niespodziewanie okazało się, że poszczególne szkice wyraźnie odbiegły od stricte literaturoznawczej perspektywy. Zamieszczone tutaj teksty poświęcone zostały narracjom z takich obszarów, jak: literatura (T. Kosz Zohar, J. Budzik, B. Przymuszała), kino (B. Kwieciński, L. Steir-Livny, E. Bauer, M. Tomczok), pośrednio

${ }^{3}$ Zob. D. Levy, N. Sznaider: The Holocaust and Memory in the Global Age. Philadelphia 2006.

${ }^{4}$ Zob. M. Rothberg: Pamięć wielokierunkowa. Pamiętanie Zagłady w epoce dekolonizacji. Przeł. K. Bojarska. Warszawa 2015.

${ }^{5}$ T. Segev: Siódmy milion. Izrael - piętno Zagłady. Przeł. B. Gadomska. Warszawa 2012.

${ }^{6}$ I. Zertal: Naród i śmierć. Zagłada w dyskursie i polityce Izraela. Przeł. J.M. KŁoczowski. Kraków 2010. 
również teatr i performans, sztuki wizualne (A. Kisiel, R. Jakubowicz), dyskurs publiczny (S. Herczyńska), pisarstwo wspomnieniowe (K. Kuczyńska-Koschany, A. Czyżak). Nie jest to jednocześnie pełna lista mediów odgrywających w Izraelu istotną rolę w opowiadaniu zagładowej pamięci. Szoa, jako jeden $\mathrm{z}$ fundamentów zbiorowej tożsamości izraelskich Żydów, stanowi stały element codzienności, przez co w stopniu znacznie wyższym niż gdziekolwiek indziej funkcjonuje w obrębie tekstów kultury popularnej, w narracjach komediowych i satyrycznych, w codziennych rozmowach, a nawet w automatyzmie skojarzeń. Żywimy nadzieję, że w miarę rozwoju polskich badań nad izraelską pamięcią o Zagładzie luki nieuchronnie obecne w stworzonym tu przez nas obrazie zostaną stopniowo zapełnione - za sprawą studiów polskich naukowców, jak również dzięki lekturze istniejących już badań izraelskich, amerykańskich itd.

Siłą rzeczy, z uwagi na interdyscyplinarny, kulturoznawczy charakter tego numeru, na pewne rozczarowanie narażeni są ci, którzy szukać będą przede wszystkim artykułów literaturoznawczych, stanowiących macierzysty kontekst pisma. Mamy świadomość, że wielu istotnych zjawisk i nazwisk (niekiedy wręcz fundamentalnych!) najzwyczajniej brakuje. Bodaj największym nieobecnym tego numeru jest zmarły niedawno Aharon Appelfeld (1932-2018). Jego bogata twórczość - kilkadziesiąt książek (począwszy od wczesnych tomów surrealistycznych opowiadań z lat 60.), z których na polski przetłumaczono jedynie dwie: Badenheim 1939 (1978) oraz Drogę żelazna (1991) ${ }^{7}$ - niemal w całości dotyka problemu niemożności wyjścia $z$ cienia Zagłady.

$\mathrm{Na}$ baczniejszą uwagę zasługują również pisarze postrealistyczni, posługujący się choćby groteską $\mathrm{w}$ celu oddania kryzysu reprezentacji. W tym kontekście szczególnie interesująca jest proza Jorama Kaniuka - Acrophile (1961), Ha-Jehudi Ha-Aharon („Ostatni Żyd”, 1982), zwłaszcza zaś sfilmowany Adam Ben Kelew („Adam, syn psa”) z 1968 roku, który nie został dotąd przetłumaczony na język polski, mimo że uznano go za być może jeden z najważniejszych prozatorskich tekstów na temat Holokaustu ${ }^{8}$. Wymienić też wypada choćby takie istotne, a pominięte w tym numerze utwory, jak: Uriego Orleva Chajal oferet („Ołowiany żołnierz”, 1956) czy Ad Machar („Do jutra”, 1958) oraz Ruth Almog Be'erec Gzeirah („Wygnanie”, 1971), a także prozę autorów tzw. drugiego pokolenia z lat 80.

7 Zob. A. Appelfeld: Badenheim 1939. Przeł. H. Szafir. Warszawa 2004; A. Appelfeld: Droga żelazna. Przeł. H. Volovici. Warszawa 2006.

${ }^{8}$ Powieść, o której mowa, nosząca w hebrajskim oryginale tytuł Adam Ben Kelew, a więc właściwie „Człowiek, syn psa” (Adam po hebrajsku to także rzeczownik pospolity, oznaczający po prostu człowieka), a w angielskim przekładzie Seymoura Simckesa - Adam Resurrected („Zmartwychwstanie Adama”), nie była nigdy w całości tłumaczona na język polski, podobnie zresztą jak inne utwory Kaniuka. Tylko częściowo usprawiedliwia to trudny, pełen groteski, surrealistyczny język autora Ostatniego Żyda. Ukazał się jedynie fragment Adama Ben Kelewa w tłumaczeniu Leszka Kwiatkowskiego pt. Adam, syn psa w „Literaturze na Świecie” 2004, nr 11/12, s. $287-311$. 
i następnych, takich jak: Nawa Semel, Itamar Levy, Sawjon Liebrecht, Dorit Peleg i wielu innych, których tutaj zabrakło. Zupełnie osobną kwestią jest nieobecność postzagładowej, izraelskiej poezji, choćby Dana Pagisa. W przyszłości warto również przyjrzeć się dokładniej temu, jak izraelska literatura eksploruje przestrzeń pomiędzy indywidualnym a zbiorowym, instytucjonalno-syjonistycznym oraz alternatywnym spojrzeniem na Zagładę, jak czynił przykładowo Jaakow Szabtaj w znakomitej, konfrontującej się z heroiczną, idealistyczną narracją ojców założycieli państwa powieści Zikhron dwarim („Czas przeszły ciągły”) z 1977 roku.

Bez wątpienia na baczniejszą uwagę zasługuje też kwestia pamięci o Zagładzie z perspektywy palestyńskiej (tu prekursorski szkic Marty Tomczok), w obrębie społecznego podziału na Aszkenazyjczyków i Mizrachim, w świetle poszczególnych aliji, na przykład rosyjskiej z lat 90., oraz zupełnie w Polsce nieznany problem reprezentacji Szoa w kręgach ultraortodoksyjnych. Warto także uwzględnić wątek wpływu prasy i innych obiegów (oficjalnych, półoficjalnych, niezależnych) na izraelską recepcję tematu Zagłady. Pozostaje nam tylko mieć nadzieję, że suma zysków z tego, co otrzymaliśmy, przeważy przedstawioną listę braków, a korzyści z poznawania kolejnych szkiców przyniosą inspiracje do dalszych poszukiwań.

Podsumowując, niniejszy, czwarty już numer „Narracji o Zagładzie” stanowi wstępną próbę zmierzenia się z całą złożonością owej sieci kontekstów i uchwycenia choćby fragmentu uwarunkowań oraz przemian wiążących się z zasadami funkcjonowania pamięci o Szoa w izraelskich narracjach. Tak rozumiany, szczególny kontekst, z którym mamy do czynienia, sprawia, że powstające $\mathrm{w}$ tym kręgu opowieści stanowią istotny i wyjątkowo interesujący - również z uwagi na swoją odmienność - rezerwuar tematów, wątków i motywów. By je uwypuklić, zrezygnowaliśmy z chronologicznego układu tekstów na rzecz tematycznego, uważając, że przecież sama pamięć także nie ma linearnego charakteru, a pojawiające się nowe tendencje niekoniecznie powodują zanik poprzednich. Stąd proponujemy spojrzeć na zebrany zestaw artykułów jako na próbę częściowej diagnozy stanu tu i teraz. Swoisty polsko-izraelski wgląd w archiwum pamięci zbiorowej, która podlega nieuchronnej konfrontacji z aktualnymi wydarzeniami kształtującymi izraelską rzeczywistość, w tym z prowadzoną przez armię okupacją i trwającym nieustannie od kilkudziesięciu lat zbrojnym konfliktem. Wszystko to skłania do postawienia pytania: co poza samą Zagładą opowiadała i opowiada izraelska narracja o niej? Na takie pytanie próbują znaleźć odpowiedź autorzy zawartych w tym numerze szkiców. Życzymy inspirującej lektury, שתהיה לכם קריאה מעניינת ומעוררת ההשרא

Jagoda Budzik Barttomiej Krupa 